\title{
Design of Productive Zakat Management Models with Social Business Insights Relating to Poverty Alleviation in Indonesia
}

\author{
Rony Wardhana ${ }^{1}$, Elfira Nurul Badriyah ${ }^{2}$, Martina Kurnia Ningsih ${ }^{3}$, Anik \\ Mubiyatiningrum ${ }^{4}$, Heru Tjaraka ${ }^{5}$ \\ rony.unnar@gmail.com ${ }^{1}$ \\ Universitas Airlangga ${ }^{1,4,5}$, Universitas Narotama ${ }^{2,3}$
}

\begin{abstract}
Social problems, especially poverty, are still issues that need to be addressed seriously. Zakat is one of the solutions that is called for by Islam to eradicate poverty and economic inequality that occurs in the midst of diverse social backgrounds. One of the models of zakat distribution that is effective in solving social problems, especially poverty alleviation, is through productive zakat. Productive zakat is zakat in the form of assets or zakat funds given to mustahiq that are not spent directly on the consumption of certain needs, but are developed and used to help their businesses so that with these efforts they can fulfill their daily needs continuously. Therefore, for this purpose to be realized, productive zakat must be managed and implemented effectively and efficiently. In many countries in the world, in recent years, entrepreneurship / social business is developing, this will be very interesting to find its relationship with the management of productive zakat. The purpose of this paper is to describe the implementation of the concept of productive zakat management in Indonesia as an alternative model of entrepreneurship / social business. The management of productive zakat with an entrepreneurial / social business perspective is expected to be able to solve poverty problems independently and sustainably, as well as to be able to provide improved living conditions for disadvantaged people in Indonesia.
\end{abstract}

Keywords: productive zakat, entrepreneurship / social business, poverty

\section{Pendahuluan}

Permasalahan sosial, khususnya kemiskinan merupakan permasalahan utama yang yang memerlukan penanganan secara serius. Kemiskinan menjadi sebuah fenomena yang tidak pernah dapat lepas dari sepanjang sejarah hidup umat manusia dan berbagai cara manusia maupun usahanya dalam mengatasi permasalahan kemiskinan tersebut. Bank Dunia (World Bank) yang menyajikan data dalam Poverty and Shared Prosperity, ada 1sebanyak $0,7 \%$ secara internasional berada pada kemiskinan. Terdata 767.000 .00 o hidup pada garis kemiskinan. dimana dalam proses pengeluaran untuk mendapatkan kebutuhan kesehariannya sebesar US\$ 1,90 dalam seharinya dimana kalau dikonfersi ke rupiah besarnya adalah berkisar Rp 25.000 disetiap harinya. 
Pada bulan Maret 2017 di Indonesia terdapat angka kemiskinan mencpai 27.770.000 manusia atau setara dengan 10,64\% bertambah dengan besaran 690.000 dibandingkan dengan data September 2016 sebesar 27.760.000 atau setara dengan 10,70\% dari jumlah penduduk Indonesia (BPS, 2017). Pemerintah Indonesia sendiri sudah mengerahkan daya dan upaya untuk menanggulangi kemiskinan dan meningkatkan kemakmuran rakyat, seperti menjaga stabilitas harga, pelaksanaan program subsidi dan bergulirnya dana desa dimana harapannya menjadi salah satu kegiatan dalam hal penanggulangan kemiskinan di daerah desa, pemberian bantuan sosial ataupun anggaran yang dialokasikan untuk mewujudkan swasembada pangan, tetapi halini masih kurang efisien karena batas kemiskinan berpengaruh terhadap angka kemiskinan bulan September 2017 sebesar 73,35\% (BPS, 2017).

Suatu pemecahan masalah akan kemiskinan yang tepat salah satunya dengan melalui model ekonomi berbagi (sharing economy). Ekonomi berbagi dan tingkat kesejahteraan dipercaya memiliki korelasi yang kuat. Swiercz dan Smith dalam Beik (2009), mengembangkan model mekanisme berbagi yang menawarkan solusi untuk menghadapi berbagai permasalahan resesi ekonomi, khususnya masalah kemiskinan.

Konsep ekonomi berbagi di Indonesia diterapkan dengan pendekatan ekonomi syariah melalui pendistribusian zakat, infak, sedekah dan wakaf. Sebagai negara yang berpenduduk mayoritas muslim yakni 207.176.162 penduduk muslim Indonesia (BPS,2010), Penduduk muslim Indonesia wajib membayar zakat dan diharapkan menyisihkan hartanya untuk infak, sedekah dan wakaf demi kepentingan sosial. Berdasarkan hal tersebut, potensi zakat, infak, sedekah, dan wakaf dapat digunakan untuk sharing economy yang memberikan dampak positif dalam hal pembangunan (Beik, 2008).

Kewajiban zakat banyak disebutkan ayat Alquran dan hadits. Hampir setiap ayat Al-Quran mengenai perintah sholat selalu diiringi pula dengan perintah berzakat. QS. Al- Baqarah: 110 berbunyi:

"Dan dirikanlah salat dan tunaikanlah zakat. Dan kebaikan apa saja yang kamu usahakan bagi dirimu, tentu kamu akan mendapat pahala nya pada sisi Allah. Sesungguhnya Alah Maha Melihat apa-apa yang kamu kerjakan (Q.S. Al-Baqarah : 110)"

Dari ayat ini menunjukkan bahwa Allah SWT mensejajarkan salat dengan zakat. Hal tersebut ditafsirkan jika kewajiban mengeluarkan zakat bagi seorang muslim tidak kalah pentingnya dengan kewajiban melaksanakan salat lima waktu. Zakat menjadi diharapkan menjadi sebuah solusi untuk menanggulangi keiskinan atau bahkan dapat menghapus kemiskinan yang terjadi di tengah latar belakang sosial masyarakat yang beragam.

Penelitian Subarkah (2016) mengatakan dampak positif zakat dapat dilihat dengan pertumbuhan produk domestik bruto (PDB), ketika PDB mengalmi kenaikan maka zakat berpotensi bisa bergerak secara positif. Dengan dasar penilaian tersebut, pada tahun 2010, BAZNAS dan IPB telah melakukan riset yang memiliki temuan bahwa secara nasional potensi zakat diperkirakan sebesar Rp 217 triliun setiap tahun. Bahkan, pada tahun 2016, potensi zakat bertambah menjadi sekitar Rp 274 triliun. Penelitian Beik (2009) menjelaskan potensi zakat dapat mengurangi kemiskinan dari angka $84 \%$ menjadi $74 \%$ atau terjasi penurunan sebesar $10 \%$.

Penerapan zakat produktis untuk mustahiq sudah ada sejak zaman Rasullah SAW sebagaimana diriwayatkan dalam hadis Imam Muslim dari salim bin Abdillah bin Umar, bahwa Rasullah SAW membagikan zakat agar dapat bisa dikembangkan nantinya dapat memberikannya kembali kepada kaum yang lainnya. Hadist ini memberikan beberapa pelajaran diantaranya ada 
porsi dana yang dipergunakan dalam mengembangkan aspek usaha produktif mustahiq, sedangkan pelajaran yang lainnya ada orientasi bahwa zakat ini dapat mengubah kondisi dari mustahiq menjadi muzakki.

Diantara model dalam penggunaan operasional zakat yang efektif dapat digunakan menanggulangi masalah kemiskinan dan kesenjangan kemiskinan malalui zakat yang produktif. zakat produktif ini maksudnya adalah dalam penggunaaannya tidak dihabiskan secara langsung dalam pemenuhan kehidupan sehari-harinya tetapi harapannya ada penyisihan dana yang dapat digunakan untuk usaha lainnya, usaha ini diharapkan dapat berkembang sehingga menunjang dalam kehidupan kesehariannya dikemudian hari bahkan diharapkan dapat memberikan zakat untuk membantu mustahiq lainnya. Dengan demikian, fokus karya ilmiah ini adalah bagaimana implementasi konsep pengelolaan zakat produktif di Indonesia berpeluang sebagai alternatif model kewirausahaan sosial.

\section{Tinjauan Pustaka}

\subsection{Mustahiq Zakat Produktif}

Salah satu pilar ajaran islam yang utama adalah zakat. zakat wajib dikeluarkan untuk harta yang perhitungannya sesuai syarat tertentu yang disalurkan pada yang berhak menerimanya. disisi ekonmi zakat merupan pembagian harta dari yang kaya ke masyakat yang tidak punya (Sartika, 2008). Tujuan utama dari zakat adalah salah dapat menyelesikan permasalah sosial dimasyakat contohnya kemiskinan, pengangguran sebagaimana penelitian Sartika (2008) disebutkan tujuan zakat adalah :

1. Meningkatkan derajad dari miskin menjadi tidak miskin

2. Pemecahan permasalahan para gharimin, ibnussabil, dan mustahiq lainnya.

3. memperkuat tali silahturami antar saudara muslim

4. mengikis sifat kikir

5. Mengikis iri hati (kecemburuan sosial) dan dengki dari golongan miskin.

6. Mengurangi celah antara golongan miskin dan kaya

7. Rasa tanggungjawab bagi pemilik harta yang berlebih 8. menumbukan sikap disiplin dalam melaksanakan kewajiban

Orang yang berhak menerima zakat disebut Mustahiq. Mustahiq diatur didalam ajaran syariat islam Surat At-Taubah : 60 yaitu ada delapan golongan (asnaf) Islam membatasi peneriman zakat, delapan golongan tersebut, yaitu orang orang miskin, budak, fakir, amil zakat, mualaf, orang yang berutang, musafir, orang yang sedang berjuang dijalan Allah.

Zakat produktif adalah zakat yang berupa uang atau dana yang diberikan kepada delapan kelompok untuk menjadi modal usaha yang sedang ataupun akan dijalankan. Mustahiq zakat produktif sendiri orang yang sedang yang sedang berusaha tetapi hasil dari usahanya tidak dapat mencukupi kebutuhan untuk makan dan minum (Farid, Sukarno, \& Puspitasari, 2013). Ketidakmampuan tersebut dipercaya dapat dipenuhi dari sumber lain seperti hutang atau dengan cara meningkatkan usaha yang dimiliki, disisi lain zakat produktif dapat diberikan pengertian sebuah zakat berbentuk dana zakat atau harta yang diberikan kepada mustahiq yang tidak habis dalam pemenuhan konsumsi kesehariannya tetapi dapat berkembang untuk usaha mereka (Asnaini, 2008). 


\subsection{Zakat Produktif dan Kewirausahaan Sosial}

Dalam penelitian Beik (2010) menyatakan zakat memiliki tiga dimensi (1) dimensi spiritual personal perwujudan iman manusia kepada Allah, (2) dimensi sosial diharpkan dapat terbentuknya hubungan antar manusia sehingga dapat membentuk pertahanan nasional dan mengikis jurang perbedaan antar yang kaya dan miskin, (3) dimensi ekonomi yang terbagi dalam 2 hal yaitu pertumbuhan ekonomi berkeadilan (QS. 30: 39) dan konsep sharing perekonomian (QS. 51: 19). Dari ketiga konsep tersebut, dapat dikatakan bahwa zakat lebih mengarah pada tujuan sosial yang memperhatikan kepedulian kepada sesama, memperhatikan kondisi sosial masyarakat, dan memperhatikan pertumbukan ekonomi berkeadilan dan mekanisme sharing dalam perekonomian.

Untuk dapat mewujudkan tujuan zakat dalam memberantas kemiskinan, maka diperlukan sebuah pendekatan baru dalam pengelolaan zakat produktif, yaitu dengan konsep kewirausahaan sosial. Konsep kewirausahaan sosial dapat membentuk bisnis baru dengan melibatkan dan memberdayakan masyarakat. Untuk mengukur keberhasilan dari konsep kewiarusahaan sosial yang efektif dan efisien yaitu dilihat dari bagaimana masyarakat dapat terbantukan dengan program ini.

Untuk mengetahui relasi zakat produktif dengan kewirausahaan sosial, maka perlu digali kembali peran kewirausahaan sosial dalam pembangunan ekonomi. Adapun peran kewirausahaan sosial (Syari'ah et al., 2017) dapat (1) Menciptakan lapangan kerja, (2) Inovasi dan kreatifitas dalam menyediakan barang dan jasa (3) Modal Sosial (4) Kesejahteraan yang meningkat.

\subsection{Konsep Pengelolaan Zakat Produktif di Indonesia}

Tata kelola zakat diatur dalam Undang-Undang (UU) Nomor 23 Tahun 2011. Pasal 3 dimana zakat bertujuan untuk (a) peningkatan efisiensi dan efektif di dalam pelayanan pengelolaan zakat, (b) pemanfaatan zakat guna terwujudnya masyarakat yang sejahtera dan mengurangi kemiskinan. dalam pasal 27 bab 3 dijelaskan bahwa zakat bisa digunakan untuk penanggulangan kemiskinan dan kualitas sumber daya manusia dapat ditingkatkan hal ini dapat terwujud apabila kebutuhan mendasar dari mustahiq dapat terpenuhi.

Distribusi Zakat dikelompokkan menjadi beberapa kelompok diantaranya kesatu: bersifat konsumtif-tradisional, dimana zakat yang langsung digunakan langsung oleh mustahiq seperti zakat fitrah. Kedua: bersifat konsumtif-kreatif, zakat dalam bentuk lain bisa dalam bentuk pendidikan. Ketiga, bersifat produktif-tradisional, zakat dalam bentuk barang produktif dan keempat, bersifat produktif-kreatif, zakat digunakan dalam bentuk dayaguna usaha mandiri (Edi, 2001) dalam (Firmansyah, 2013). Pemanfaatan produktif-tradisional dan produktif-kreatif, merupakan langkah inovatif dalam pemberdayaan dan peningkatan perekonomian umat.

\section{Metodelogi Penelitian}

Untuk menjawab dari tujuan penelitian ini peneliti menggunakan mendekatan studi kasus. Metode studi kasus dapat menjawab dari penelitian ini tentang bagaimana implementasi konsep pengelolaan zakat produktif di Indonesia berpeluang sebagai alternatif model kewirausahaan sosial.

Sumber data diperoleh langsung dari responden atau informan dengan menggunakan tehnik wawancara langsung sehingga memudahkan peneliti untuk menganalisis permasalahan, 
sedangkan data pendukung diperoleh dari buku-buku mengenai zakat, jurnal-jurnal, peraturan perundang-undangan, dan penelitian sebelumnya.

\section{Hasil dan Pembahasan}

Bank Dunia (World Bank) merilis sebuah publikasi laporan Poverty and Shared Prosperity di akhir tahun 2016, Populasi global di dunia sedikitnya $10,7 \%$ berada di dalam ancaman kemiskinan yaitu sebesar 767.000.000 manusia hidup di bawah garis internasional kemiskinan. Para penduduk dunia tersebut memiliki pengeluaran untuk hidup sejumlah US\$ 1,90 di tiap harinya atau sekitar Rp 25.000 per harinya. Sementara itu, Indonesia turut menyumbang angka kemiskinannya, dari data BPS diketahui di bulan Maret 2017 penduduk miskin di Indonesia berjumlah 27.770 .000 orang, bertambah sebesar 690.000 orang dibandingkan pada bulan September 2016 yang sebesar 27.760 .000 orang atau berkisar 10,70\% dari jumlah penduduk Indonesia (BPS, 2017).

Walaupun pemerintah Indonesia sudah melakukan berbagai cara dan upaya yang tertuang dalam kebijakannya untuk mengentaskan angka kemiskinan dengan mengeluarkan kebijakan tentang stabilitas harga, subsidi dana desa, serta bantuan sosial. Pemerintah juga mentargetkan jumlah kemiskinan sebesar tujuh sampai delapan persen pada tahun 2019 sebagaimana yang tertulis dalam kebijakan Rencana Pembangunan Jangka Menengah Nasional (RPJMN) tahun 2014-2019. Indonesia diprediksi masih akan menjadi penyumbang angka kemiskinan menempati 100 besar negara yang memiliki angka kemiskinan yang cukup tinggi. Hal ini disebabkan kinerja penurunan kemiskinan yang dapat dianggap tidak berkurang, dan justru bertambah. Data Badan Pusat Statistik (BPS) menyajikan di semester I bulan Maret 2017, di Perdesaan adalah 361.496 sementara di Perkotaan berjumlah 385.621. Sedangkan jumlah penduduk miskin Indonesia pada semester ke-2 di bulan September 2017, di Perdesaan adalah 370.910 dan di Perkotaan berjumlah 400.995.

Tabel 1: Data Kemiskinan, Prosentase dan Garis Kemiskinan, 2011-2017

\begin{tabular}{|l|c|c|c|c|c|c|c|c|}
\multirow{2}{*}{\begin{tabular}{c} 
Years \\
\cline { 3 - 9 }
\end{tabular}} & \multicolumn{3}{|c|}{$\begin{array}{c}\text { Jumlah Penduduk Miskin (juta } \\
\text { orang) }\end{array}$} & \multicolumn{2}{c|}{ Persemtase Penduduk Miskin } & \multicolumn{2}{c|}{$\begin{array}{c}\text { Garis Kemiskinan } \\
\text { (Rp/Kapita/Bulan) }\end{array}$} \\
\cline { 2 - 10 } & Kota & Desa & Kota+Desa & Kota & Desa & Kota+Desa & Kota & Desa \\
\hline Maret 2011 & 11,05 & 18,97 & 30,02 & 9,23 & 15,72 & 12,49 & 253.016 & 213.395 \\
\hline September 2011 & 10,95 & 18,94 & 29,89 & 9,09 & 15,59 & 12,36 & 263.594 & 223.181 \\
\hline Maret 2012 & 10,65 & 18,49 & 29,13 & 8,78 & 15,12 & 11,96 & 267.408 & 229.226 \\
\hline September 2012 & 10,51 & 18,09 & 28,59 & 8,60 & 14,70 & 11,66 & 277.382 & 240.441 \\
\hline Maret 2013 & 10,33 & 17,74 & 28,07 & 8,39 & 14,32 & 11,37 & 289.042 & 253.273 \\
\hline September 2013 & 10,63 & 17,92 & 28,55 & 8,52 & 14,42 & 11,47 & 308.826 & 275.779 \\
\hline Maret 2014 & 10,51 & 17,77 & 28,28 & 8,34 & 14,17 & 11,25 & 318.514 & 286.097 \\
\hline September 2014 & 10,36 & 17,37 & 27,73 & 8,16 & 13,76 & 10,96 & 326.853 & 296.681 \\
\hline Maret 2015 & 10,65 & 17,94 & 28,59 & 8,29 & 14,21 & 11,22 & 342.541 & 317.881 \\
\hline September 2015 & 10,62 & 17,89 & 28,51 & 8,22 & 14,09 & 11,13 & 356.378 & 333.034 \\
\hline Maret 2016 & 10,34 & 17,67 & 28,01 & 7,79 & 14,11 & 10,86 & 364.527 & 343.647 \\
\hline September 2016 & 10,49 & 17,28 & 27,76 & 7,73 & 13,96 & 10,70 & 372.114 & 350.420 \\
\hline Maret 2017 & 10,67 & 17,10 & 27,77 & 7,72 & 13,93 & 10,64 & 385.621 & 361.496 \\
\hline
\end{tabular}

Catatan: Referensi waktu untuk seluruh data adalah Februari

Tautan Sumber: https://www.bps.go.id/linkTabelStatis/view/id/1494 
Sebagaimana negara yang memiliki penduduk yang mayoritas muslim nomor satu di dunia, yakni 207.176.162 penduduk muslim Indonesia (BPS, 2010), Indonesia memiliki pendistribusian infak, zakat, sedekah dan wakaf yang tinggi. Dalam UU Nomor 23 Tahun 2011 telah dijelaskan tentang Tata kelola zakat, sebagaimana pasal 3 dinyatakan cara tatakelola zakat memiliki tujuan dalam efisiensi dan efektivitas peningkatan dan pengelolaan manfaat zakat dalam turut serta terwujudnya kesejahteraan masyarakat dan untuk menanggulangi kemiskinan.

Hukum zakat bagi umat muslim yaitu fardhu 'ain atau wajib 'aini yang mana memiliki kewajiban pribadi tidak akan mungkin diberikan kepada orang lain, dalam penghapusan kemiskinan dan kesenjangan ekonomi zakat merupakan solusinya yang terjadi di tengah latar belakang sosial masyarakat yang beragam. Q.S. At-Taubah ayat 60 berbunyi:

"Sesungguhnya zakat-zakat itu, hanyalah untuk orang-orang fakir, orang-orang miskin, pengurus-pengurus zakat, para mu'allaf yang dibujuk hatinya, untuk (memerdekakan) budak, orang-orang yang berhutang, untuk jalan Allah dan untuk mereka yuang sedang dalam perjalanan, sebagai suatu ketetapan yang diwajibkan Allah, dan Allah Maha Mengetahui lagi Maha Bijaksana (Q.S. At-Taubah: 60).”

Kitab Fiqih Madzahibul Arba'ah menyebutkan bahwa salah satu rukun Islam dan aturannya fardlu ,ain bagi orang yang memenehi peryaratannya adalah menunaikan zakat, dari sini terlihat bahwa zakat dapat berpotensi besar jika dilakukan secara rutin dan konsisten. Pada tahun 2010, BAZNAS dan IPB telah melakukan riset yang memiliki temuan bahwa zakat memiliki potensi secara nasional dapat diperkirakan sebesar Rp 217 triliun setiap tahun. Bahkan, pada tahun 2016, potensi zakat bertambah menjadi sekitar Rp 274 triliun. Beik (2009) menjelaskan bahwa zakat berpotensi dalam mengikis jumlah warga miskin yang sebelumnya diangka $84 \%$ menjadi $74 \%$.

Dipandang dalam bidang ekonomi, zakat dapat membantu dalam meningkatkan taraf kesejahteraan mustahiq. Zakat dapat menjadi pemecahan masalah akan kemiskinan yang tepat, salah satunya dengan melalui model ekonomi berbagi (sharing economy). Potensi zakat, infak, sedekah, dan wakaf dapat berdampak positif dan membangun jika dikelola secara baik (Beik, 2008). Ekonomi berbagi dengan tingkat kesejahteraan dipercaya memiliki korelasi yang kuat. Swiercz dan Smith dalam Beik (2009), mengembangkan model mekanisme berbagi yang menawarkan solusi untuk menghadapi berbagai permasalahan resesi ekonomi, khususnya masalah kemiskinan.

Di beberapa periode tahun terakhir di banyak negara, kewirausahaan sosial sedang berkembang, melalui jalur kewirausahaan sosial, seorang wirausahawan mampu menciptakan lapangan pekerjaan baru di negaranya. Hal ini yang mendorong beberapa negara menerapkan kewirausahaan sosial. Untuk urusan melahirkan entrepreneur, Amerika Serikat menjadi sering disebut sebagai beacon of entrepreneurialism. Pada tahun 1996 sampai tahun 2004, rata-rata 550.000 bisnis setiap bulan telah tercipta, banyak dari bisnis tersebut pada akhirnya bergerak dan berkembang, dan berjasa dalam penciptaan lapangan pekerjaan.

Selama ini pelaksanaan zakat di Indonesia dirasakan masih belum terarah. Sering kali zakat yang didistribukan oleh amil zakat adalah zakat konsumtif dimana zakat tersebut hanya digunakan menopang kehidupan kesehariannya dan cukup hanya membeli kebutuhan pokok sehari-hari tidak memberikan solusi untuk kedepannya dan jangka panjang mustahiq, tindakan memberikan bantuan secara langsung ke keluarga miskin mengecilkan sifat kemandirian mereka. 
Meninjau hal tersebut, masyarakat fakir dan miskin (mustahiq) harus memiliki semangat dalam mengubah keadaan hidupnya. Dalam hal ini masyarakat miskin harus diberdayakan untuk ikut andil membantu negara bangkit dari kemiskinan. Pelaksanaan zakat dianggap tidak hanya termasuk dermawan (amal karikatif), melainkan termasuk kewajiban yang bersifat otoritatif (ijbari), di mana zakat tidak seperti salat, ibadah haji dan puasa, yang pelaksanaannya dilaksanakan oleh masing-masing individu, tetapi juga ada peran serta para petugas yang amanah, terbuka, jujur dan profesional. Sehingga pertimbangan mengenai pengelolaan zakat yang melalui institusi zakat berdasarkan kepada beberapa pertimbangan, seperti menjamin kepastian dan disiplin pembayaran zakat, menjauhkan para mustahiq dari perasaan diri jika berhadapan langsung dengan pemberi zakat (muzakki), institusi pengelola zakat memiliki kecakapan dan sasaran dalam pengelolaan dana zakat sesuai urutan prioritas penggolongan mustahiq dalam keberadaannya atau di tempat, memperlihatkan bagaimana semangat ajaran agama islam dalam perwujudan operasional dan tatakelola negara dan pemerintah yang islami dalam menjamin keberlangsungan hidup para warga negaranya yang fakir dan miskin. Jenis institusi zakat yang diakui dalam Undang-Undang Nomor 23 Tahun 2011 tentang Pengurusan Zakat adalah Lembaga Amil Zakat (LAZ) dan Badan Amil Zakat Nasional (BAZNAS) serta dibantu oleh Pengumpul Zakat (UPZ).

Terdapat dua jenis pendayagunaan dana zakat yang diatur dalam Surat Keputusan Menteri Agama RI No. 373 tahun 2003 tentang dana zakat yaitu:

1. Basis Sosial

Zakat disalurkan secara sederhana berupa dana yang diberikan kepada mustahiq untuk memenuhi kebutuhan sehari-hari.

2. Basis pengembangan ekonomi

Zakat berupa modal usaha yang tatakelolanya dan operasionalnya dapat mengikutsertakan keterlibatan mustahiq. Penyaluran zakat diarahkan untuk usaha ekonomi produktif sehingga hasilnya dapat meningkatkan taraf hidup masyarakat.

Pemberdayaan dana zakat berbasis pengembangan ekonomi, menjadi langkah inovatif dalam rangka peningkatan perekonomian dan daya guna masyarakat (mustahiq), yaitu merubah paradigma zakat dari pola konsumtif menuju zakat produktif. Zakat produktif merupakan zakat dalam bentuk dana zakat atau harta yang diberikan kepada para mustahiq yang diharapkan tidak segera dihabiskan langsung untuk keperluan yang bersifat konsumtif, tetapi dpat dikembangkan dan digunakan dalam operasional usaha mereka, sehingga usaha tersebut dapat menunjang kehidupan sehari hari (Asnaini, 2008).

Optimalisasi pengelolaan zakat dapat dibagi ke dalam topologi golongan mustahiq menjadi tiga kriteria,

1. Golongan yang tidak mempunyai kemampuan sama sekali/tidak siap untuk berusaha karena beberapa faktor usia (lansia) atau karena cacat jasmani, maka cara yang dilakukan adalah memberikan jaminan hidup secara rutin dari dana zakat atau dimasukkan ke panti sosial, dan diberikan bantuan zakat dalam bentuk konsumtif.

2. Mereka yang masih tergolong sehat secara fisik dan jasmani/siap berwirausaha, tetapi tidak memiliki keterampilan apapun. Golongan ini diberikan pelatihan dan pendidikan yang mungkin dilakukan atau ditempatkan pada unit-unit usaha yang dikelola oleh amil zakat setempat sehingga mereka dapat lebih mandiri dalam memenuhi kebutuhan hidupnya.

3. Mereka miskin karena suatu hal yang disebabkan terjadi musibah sedangkan fisik dan mentalnya masih berpotensi untuk bekerja dan berusaha, tetapi tidak memiliki 
modal, maka cara yang dilakukan adalah dengan memberikan pinjaman modal usaha dari dana zakat (Wulansari, 2013: 31) dalam (Najma, 2014).

Berdasarkan pemaparan tipologi golongan mustahiq di atas, dapat diambil sebuah ikhtisar penilaian, jika pada tipologi golongan pertama yaitu mustahiq yang tidak siap melakukan wirausaha (belum siap diberikan zakat produktif), sementara pada tipologi golongan mustahiq kedua dan ketiga, mustahiq yang siap melakukan usaha dapat diberdayakan menjadi muzakki untuk mengelola usaha dengan prinsip kewirausahaan sosial.

Tabel 2: Penyaluran Zakat Berdasarkan Ashnaf di setiap Organisasi Pengelola Zakat (OPZ)

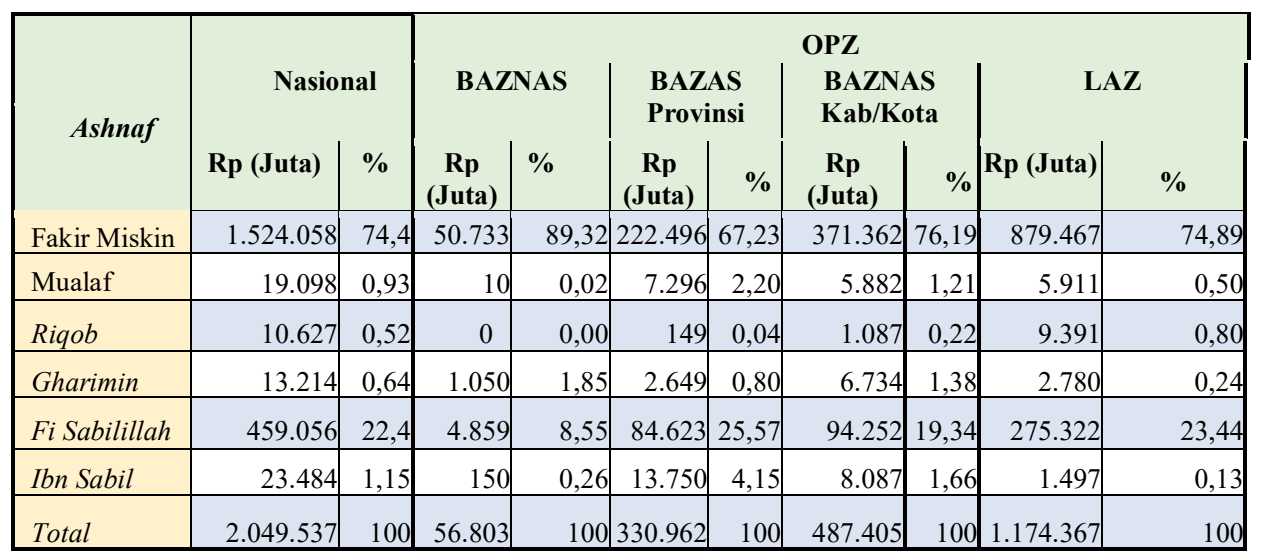

Sumber : Dokumen statistik BAZNAS (2016)

Berdasarkan pada data perolehan Zakat, Infaq, Shodaqoh nasional pada tahun 2015 menyatakan jika sebesar 74,4\% total sakat yang bukan untuk amil dialokasikan untuk kelompok kurang mampu atau fakir dan miskin yakni sekitar satu setengah trilliun rupiah, yang berarti kelompok kurang mampu atau fakir dan miskin merupakan penerima dana zakat tertinggi sekitar lebih dari 50\% keseluruhan dari dana zakat yang terkumpul di Organisasi Pengelolaan Zakat (OPZ). 


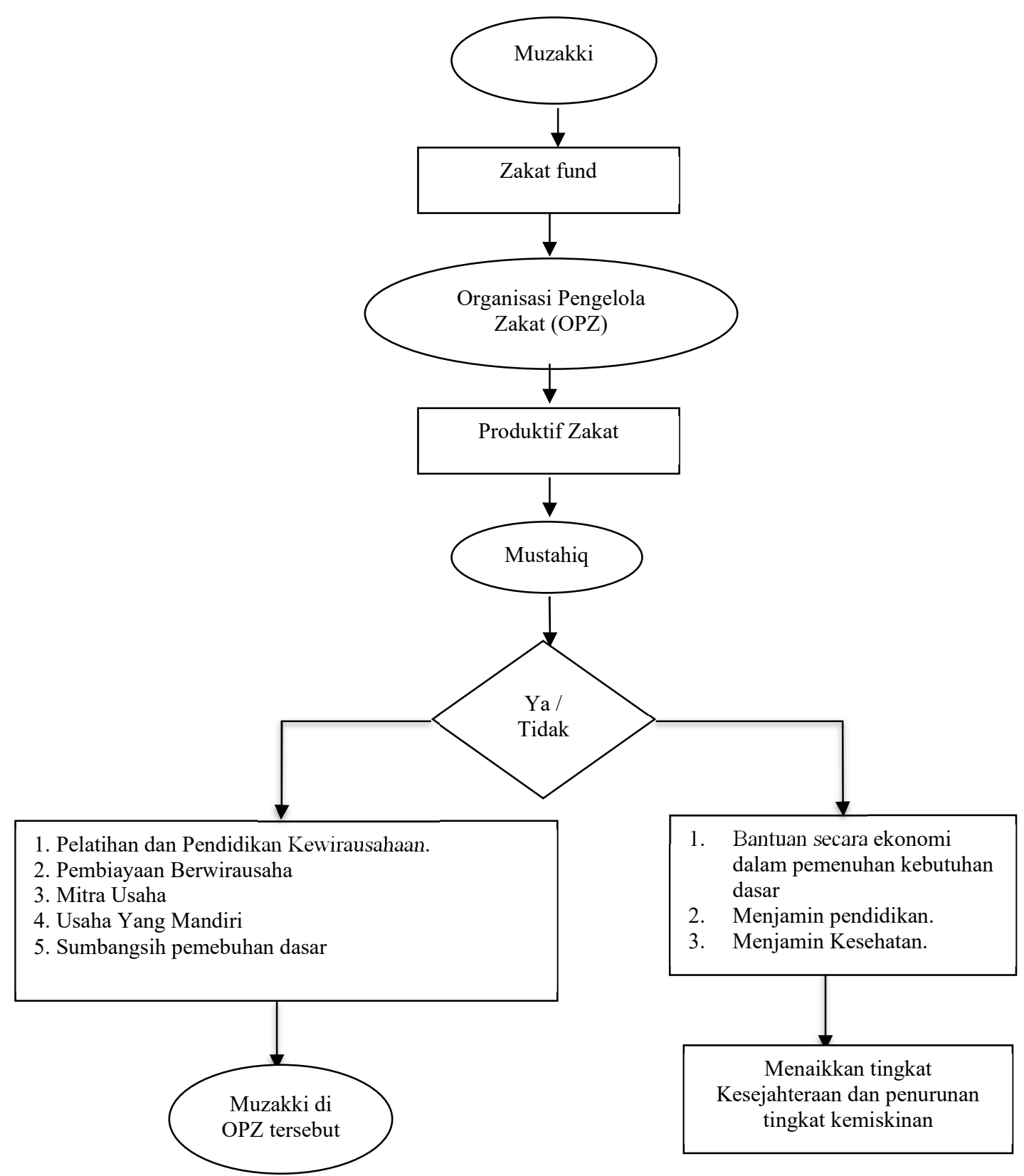

Gambar 1: Model Pengelolaan Zakat Produktif Berwawasan Kewirausahaan Sosial

Sumber : data diolah dari peneliti 
Pendistribusian dana zakat produktif dapat dikelola dengan penyaluran menerapkan model penyaluran Zakat yang produktif yang disajikan dalam tulisan ini.

Dalam model tatakelola zakat produktif berpandangan wirausaha sosial yang penulis telah desain sebelumnya, dapat dirumuskan implementasi tatakelola zakat produktif berwawasan berpandangan wirausaha sosial dalam kaitannya dengan pengentasan kemiskinan sebagai berikut: penyaluran zakat dimulai dengan menyalurkan dana zakat kepada Organisasi Pengelola Zakat (OPZ), kemudian dana zakat tersebut akan diberikan kepada mustahiq berupa zakat produktif. Bagi mustahiq yang tidak siap mengelola zakat produktifnya, zakat yang diberikan akan dikhususkan dalam bentuk bantuan ekonomi dalam pemenuhan kebutuhan dasar (basic needs), menjaminan pendidikan, jaminan kesehatan, yang mana keseluruhannya diharapkan dapat meningkatkan kesejahteraan dan menurunnya tingkat kemiskinan. Namun bagi mustahiq yang mampu dan siap untuk mengelola dana zakat produktifnya, diharapkan dana zakat produktif yang diberikan oleh muzakki tersebut dapat dimanfaatkan sebagai beasiswa pendidikan dan pelatihan usaha mandiri, pembiayaan usaha maupun kemitraan usaha, dan dapat menjadi bantuan secara ekonomi dalam pemenuhan kebutuhan dasar

Adapun alokasi dana zakat produktif untuk dapat dikelola dengan memberikan modal dan mengembangkan ekonomi mustahiq fakir miskin melalui bantuan usaha kecil dengan program bimbingan beserta pendampingan, pengembangan potensi agrobis berbasis kearifan lokal, serta pemberdayaan masyarakat dalam mengembangkan pengembangan usaha riil. Program bimbingan beserta pendampingan yang dimaksud adalah pelatihan yang diberikan berupa pengelolaan keuangan sederhana, pada pelatihan tersebut mustahiq juga menerima bantuan pembiayaan berupa modal usaha. Dalam pelatihan pengelolaan keuangan sederhana ini, mustahiq diedukasi untuk memilah pengelolaan atas hasil usahanya nanti menjadi tiga pembagian, yaitu pertama memilah bantuan dana zakat produktifnya menjadi modal usaha, kedua menjadi abungan pengembangan usaha, ketiga yang paling akhir adalah sebagai cadangan dalam memenuhi kebutuhan sehari - hari untuk keperluan konsumsinya. Pada tahap akhir, ketika mustahiq telah menjalankan usaha, Organisasi Pengelola Zakat (OPZ) melakukan serangkaian monitoring dan evaluasi atas jumlah dana zakat produktif yang telah terserap dan kinerja usaha mustahiq berupa perencanaan usaha, kemampuan mengelola dana zakat produktif. Hasil akhir yang diharapkan kepada mustahiq penerima zakat produktif adalah mustahiq tersebut memiliki usaha yang dikelola dan dapat membiayai kebutuhan hidupnya beserta keluarganya nantinya, sehingga pada saat usaha mustahiq tersebut berhasil, maka hasil jangka panjangnya adalah mustahiq sebagai penerima dana zakat produktif di awal dapat berubah menjadi muzakki di Organisasi Pengelola Zakat (OPZ) tersebut dengan taraf kemapanan ekonomi yang dinilai telah memenuhi kriteria untuk menjadi muzakki.

Berdasarkan perihal tersebut zakat produktif dilakukan dengan tujuan menigkatkan kesejahteraan masyarakat dan pengentasan kemiskinan bergelombang dan berkesinambungan, sehingga cara ini secara lansung membantu program pemerintah untuk mengurangi angka kemiskinan.

\section{Kesimpulan}

Kewajiban mengeluarkan zakat bagi seorang muslim tidak kalah pentingnya dengan kewajiban melaksanakan salat lima waktu. Zakat menjadi alternatif pengurangan kemiskinan dan kesenjangan sosial yang terjadi di tengah latar belakang sosial masyarakat yang beragam. Zakat produktif merupakan zakat dalam bentuk harta atau dana zakat yang diberikan kepada para mustahiq 
Tipologi golongan mustahiq yang termasuk kriteria penerima zakat produktif yaitu orang fakir dan miskin sehat jasmani dan rohani siap berwirausaha, tetapi tidak memiliki keterampilan apa pun. Karakteristik berikutnya, orang fakir dan miskin karena musibah, jasmani dan rohani masih berpotensi untuk bekerja dan berusaha. Desain model tatakelola zakat produktif berpandangan kewirausahaan yaitu : penyaluran zakat dimulai dengan menyalurkan dana zakat kepada Organisasi Pengelola Zakat (OPZ), kemudian dana zakat tersebut akan diberikan kepada mustahiq berupa zakat produktif.

Mustahiq telah menjalankan usaha yang berjalan sesuai program zakat produktif yang dikelola oleh Organisasi Pengelola Zakat (OPZ) termasuk ke dalam fase selanjutnya. Organisasi Pengelola Zakat (OPZ) melakukan serangkaian monitoring dan evaluasi atas jumlah dana zakat produktif yang telah terserap dan kinerja usaha mustahiq berupa perencanaan usaha, kemampuan mengelola dana zakat produktif. Hasil akhir yang diharapkan kepada mustahiq penerima zakat produktif adalah mustahiq tersebut memiliki usaha yang dikelola dan dapat membiayai kebutuhan hidupnya beserta keluarganya nantinya, sehingga pada saat usaha mustahiq tersebut berhasil, maka hasil jangka panjangnya adalah mustahiq sebagai penerima dana zakat produktif di awal dapat berubah menjadi muzakki di Organisasi Pengelola Zakat (OPZ) tersebut dengan taraf kemapanan ekonomi yang dinilai telah memenuhi kriteria untuk menjadi muzakki.

\section{REFERENCES}

[1] Abdurrahman Al-Jaziri, al-Fiqih 'Ala Madzahib al-Arba'ah, Beirut: Dar al-Qalam, t.t.

[2] Asnaini, (2008) Zakat Produktif dalam Perspektif Hukum Islam, Yogyakarta: Pustaka Pelajar.

[3] Beik, I. S. 2010. Economic Role of Zakat in Reducing Poverty and Income Inequality in the Province of DKI Jakarta, Indonesia: Case Study of the Government Board of Zakat and Dhompet Dhuafa Republika. International Islamic University Malaysia. Kuala Lumpur.

[4] Beik, I. S. (2015). Analisis Peran Zakat dalam Mengurangi Kemiskinan: Studi Kasus Dompet Dhuafa Republika, (January 2009).

[5] Canggih, C., Fikriyah, K., \& Surabaya, U. N. (2017). Potensi dan realisasi dana zakat indonesia, 1, 14-26.

[6] Farid, M., Sukarno, H., \& Puspitasari, N. (2013). Analisis Dampak Penyaluran Zakat Produktif Terhadap Keuntungan Usaha Mustahiq The Analysis of Distribution Effect on Productive Zakat Toward Mustahiq â€TM s Profit, 1-8.

[7] Firmansyah. (2013). Zakat sebagai instrumen pengentasan kemiskinan dan kesenjangan pendapatan, 179-190.

[8] Hujjatullah Fazlurrahman, Ahmad Ajib Ridlwan, H. K. H. (2017). Peningkatan Motivasi

Wirausaha dan Pengelolaan Keuangan Sederhana Bagi Mustahiq Zakat Produktif, 1, 37-43.

[9] Jailani, M. S., Richie, J., \& Bikley, B. (2013). Ragam Penelitian Qualitatif (Ethnografi , Fenomenologi, Grounded Theory, dan Studi Kasus ), 4.

[10] Najma, S. (2014). Optimalisasi Peran Zakat untuk Pengembangan Kewirausahaan Umat Islam, XVI(1), 143-174.

[11] Nova Rini, Nurul Huda, Yosi Mardoni, P. P. (2012). Peran Dana Zakat Dalam Mengurangi Ketimpangan Pendapatan Dan Kemiskinan, (80), 108-127

[12] Outlook Zakat Indonesia. (2016). 
[13] Purbasari, I. (2015). Pengelolaan zakat oleh badan dan lembaga amil zakat di surabaya dan gresik *, 27, 68-81.

[14] Sartika, M. (2008). Pengaruh Pendayagunaan Zakat Produktif terhadap Pemberdayaan Mustahiq pada LAZ Yayasan Solo Peduli Surakarta. Jurnal La Riba (Jurnal Ekonomi Islam), 2(1), 75-89. Retrieved from http://journal.uii.ac.id/index.php/JEI/article/view/163

[15] Subarkah, Muhammad. 2016. Potensi Zakat Nasional Mencapai Rp 217 Triliun. Retrieved from http://khazanah.republika.co.id/berita/duniaislam/wakaf/16/01/21/o1b126385- potensi-zakatnasional-mencapai-rp217-triliun-part1

[16] Syari 'ah, F., Surakarta, I., Zakat, P., Berwawasan, P., Sosial, K., Kemiskinan, P., Efendi, M. (2017). Pengelolaan Zakat Produktif Berwawasan Kewirausahaan Sosial Dalam Pengentasan Kemiskinan Di Indonesia, 2(1), 2527-8169.

[17] UU No.23 Tahun 2011 tentang Pengelolaan Zakat

[18] Widiastuti, T. (2015). Model Pendayagunaan Zakat Produktif Oleh Lembaga Zakat, 1(1), 89- 102 